\title{
Impacts of warming and changes in precipitation frequency on the regeneration of two Acer species
}

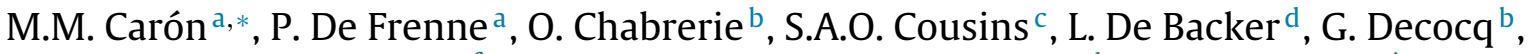 \\ M. Diekmann ${ }^{\mathrm{e}}$, T. Heinken ${ }^{\mathrm{f}}$, A. Kolb ${ }^{\mathrm{e}}, \mathrm{T}^{\mathrm{T}}$ Naaf $^{\mathrm{g}}$, J. Plue ${ }^{\mathrm{c}}$, F. Selvi ${ }^{\mathrm{h}}$, G.R. Strimbeck ${ }^{\mathrm{i}}$, \\ M. Wulf ${ }^{g}$, K. Verheyen ${ }^{\mathrm{a}}$ \\ a Forest \& Nature Lab, Ghent University, Gontrode-Melle, Belgium \\ b Jules Verne University of Picardie, UR Ecologie et Dynamique des Systèmes Anthropisés (EDYSAN, FRE 3498 CNRS-UPJV), 1 rue des Louvels, F-80037 \\ Amiens Cedex 1, France \\ ${ }^{c}$ Department of Physical Geography and Quaternary Geology, Stockholm University, Stockholm, Sweden \\ 'Sylva nurseries BVBA, Waarschoot, Belgium \\ e Vegetation Ecology and Conservation Biology, Institute of Ecology, FB2, University of Bremen, Bremen, Germany \\ ${ }^{\mathrm{f}}$ Biodiversity and Systematic Botany, Institute of Biochemistry and Biology, University of Potsdam, Potsdam, Germany \\ $\mathrm{g}$ Institute of Land Use Systems, Leibniz-Centre for Agricultural Landscape Research (ZALF) Müncheberg, Germany \\ ${ }^{\mathrm{h}}$ Department of Agrifood Production and Environmental Sciences, Section of Soil and Plant Sciences University of Florence, Firenze, Italy \\ ${ }^{i}$ Department of Biology, Norwegian University of Science and Technology, Trondheim, Norway
}

\section{A R T I C L E I N F O}

\section{Article history:}

Received 16 September 2014

Received in revised form 20 May 2015

Accepted 21 May 2015

Available online 22 May 2015

\section{Keywords:}

Seed provenance

Germination

Climate change

Interactive effects

\begin{abstract}
A B S T R A C T
Climate projections indicate that temperatures will increase by up to $4.5^{\circ} \mathrm{C}$ in Europe by the end of this century, and that more extreme rainfall events and longer intervening dry periods will take place. Climate change will likely affect all phases of the life cycle of plants, but plant reproduction has been suggested to be especially sensitive. Here, using a combination of approaches (soil heaters and different provenances along a latitudinal gradient), we analyzed the regeneration from seeds of Acer platanoides and $A$. pseudoplatanus, two tree species considered, from a management point of view, of secondary relevance. We studied germination, seedling survival and growth in a full-factorial experiment including warming and changes in watering frequency. Both species responded to warming, watering frequency and seed provenance, with stronger (negative) effects of warming and provenance than of watering frequency. In general, the central provenances performed better than the northernmost and southernmost provenances. We also detected interactive effects between warming, watering frequency and/or seed provenance. Based on these results, both species are expected to show dissimilar responses to the changes in the studied climatic factors, but also the impacts of climate change on the different phases of plant regeneration may differ in direction and magnitude. In general increases in the precipitation, frequency will stimulate germination while warming will reduce survival and growth. Moreover, the frequent divergent responses of seedlings along the latitudinal gradient suggest that climate change will likely have heterogeneous impacts across Europe, with stronger impacts in the northern and southern parts of the species' distribution ranges.
\end{abstract}

(c) 2015 Elsevier GmbH. All rights reserved.

\section{Introduction}

Depending on the concentration-driven scenario considered (suite of greenhouse gases, aerosols and chemically active gases), a future increase of the average annual temperature between $0.6^{\circ} \mathrm{C}$

\footnotetext{
* Corresponding author. Tel.: +3292649036.

E-mail addresses: MariaMercedes.Caron@UGent.be, mechicaron@gmail.com (M.M. Carón).
}

and $4.5^{\circ} \mathrm{C}$ is expected in Europe by the end of this century (IPCC 2013). The projections predict that the winter mean temperature will rise more in Northern Europe than in Central Europe and the Mediterranean area while the summer warming will likely be more intense in the Mediterranean area and Central Europe than in Northern Europe (Christensen et al., 2013). Extreme events of warming are also expected; the length, frequency, and/or intensity of warm periods are expected to increase (IPCC, 2013). As a consequence of global warming, the water cycle is also expected to change non-uniformly. Precipitation frequencies will be likely 
modified, with more extreme rainfall events and longer dry intervals (Chaoyang et al., 2012; IPCC, 2012, 2013). However, not only the changes in individual factors will be important in the future. The interaction between different climatic factors can produce different impacts on terrestrial ecosystems compared to the effects of individual factors; for example, the combination of drought, extreme heat and/or low humidity will clearly have stronger impacts than any factor alone (IPCC, 2012, 2013). Additionally, changes in climatic factors can induce changes in other abiotic environmental factors. For instance, soil moisture is the result of a combination of different abiotic factors such as precipitation, temperature, air humidity, soil texture and organic matter content (Wang, 2005; Chaoyang et al., 2012; Schneider et al., 2014).

Even though the changes in climatic drivers and other related abiotic aspects are expected to be larger at the end of the century, the effects of current global warming are already visible in several ecosystems (Hedhly et al., 2008; Van Mantgem et al., 2009) and affect the ecology of many species, including their geographical distribution, phenology, biotic interactions and extinction risks (for a review see Peñuelas et al., 2013). Temperature has been shown to influence seed production (Walck et al., 2011; Carón et al., 2014a), germination, establishment (Lewis et al., 1999; Jensen, 2001) and growth of plants (Rapp et al., 2012). Rainfall amount or soil moisture content may affect plant distributions (North et al., 2005), seed germination (Fay \& Schultz, 2009,b; Carón et al., 2014a,b), growth (Fay and Schultz, 2009; Dreesen et al., 2012), phenology (Seghieri et al., 2009), and mortality (Anderegg et al., 2013). However, changes of different climatic factors have not received the same level of attention. For instance, the impacts of changes in precipitation frequency are rarely assessed (but see e.g. Fay et al., 2003; Chaoyang et al., 2012; Schneider et al., 2014). Precipitation frequency may change separately from rainfall totals when the total amount of rainfall over a certain period remains constant, but the number of rainfall events decreases and the precipitation amount in each rainfall event increases. Some of the few available studies on plants have shown that reduced rainfall frequencies can increase productivity, decrease root-to-shoot ratios or affect leaf senescence in grassland species (Fay et al., 2003, 2002; Schneider et al., 2014). Yet, more research is urgently needed to better understand the effect of changes in precipitation frequency on other plant growth parameters, functional groups, and ecosystems (Schneider et al., 2014).

Even though climate change will likely affect all plant life cycle phases, plant reproduction has been suggested to be especially sensitive (Hedhly et al., 2008; Walck et al., 2011). In many cases, warming has been shown to positively influence seed germination (Milbau et al., 2009; McCarragher et al., 2011) or to enhance seedling survival and growth (Piper et al., 2013). In contrast, reduced soil moisture contents tend to negatively affect seed germination and seedling survival and growth (Fay and Schultz, 2009; Shevtsova et al., 2009). Information about the impacts of climate change on regeneration from seeds is essential for tree species because it is the most common natural way through which forests regenerate around the globe. In practice, the majority of tree species used for afforestation or reforestation in Europe are grown from seeds (Den Ouden et al., 2010). Throughout Europe, young trees that are used for reforestation and afforestation generally come from a pool of recommended and/or autochthonous provenances ( $\mathrm{cf}$. the EU Directive 1999/105/EC on the marketing of forest reproductive material). However, only very limited information is available on how these recommended provenances will perform under future climatic conditions.

Here, we analyze the effects of warming and changed watering frequency on regeneration from seeds of two important, currently secondary tree species in forest management, namely A. platanoides and $A$. pseudoplatanus. Both species might become more abundant in the context of climate change due to the projected composi- tional change in European forests as a consequence of the decline in fitness and abundance of currently primary species such as Picea abies and Fagus sylvatica (Hanewinkel et al., 2012). We analyze the impacts of warming and changes in precipitation frequency (as simulated by various watering intervals) on germination and early establishment of these two Acer species from different European provenances. A variety of techniques are available to study the effects of climate change on plant species including soil heating cables, open top chambers, growth chambers, and natural climatic gradients such as those across latitudes or elevations (Carón et al., 2015; De Frenne et al., 2013; Deines et al., 2007; Dunnett and Grime, 1999). The technique selected in each case depends on several factors including the life cycle phase that is being investigated. Here, we combine the use of soil heating mats (Carón et al., 2014a) with seed collection along a latitudinal gradient (Fukami and Wardle, 2005; De Frenne et al., 2013). The combination of various techniques constitutes an interesting step further, relative to the use of only one technique because it allows to illuminate the impacts of climate change on different aspects of plant populations such as different phases of plant reproduction (De Frenne et al., 2013).

We specifically address (i) How do warming and changes in watering frequency affect seed germination, seedling survival and growth? (ii) Is there an interacting effect of warming and watering frequency on tree species' regeneration? (iii) Is there a variation in the seed and seedlings response to changes in temperature and watering frequency according to the provenance of the seeds? We hypothesize that the seeds and seedlings from mother trees from southern provenances will be able to better cope with interactive warming and less frequent watering than the seeds and seedlings from mother trees growing under colder and wetter northerly conditions. Additionally, we expect that warming will enhance seedling survival and growth and that more frequent watering will stimulate germination.

\section{Material and methods}

\subsection{Study species}

Acer platanoides L. and A. pseudoplatanus L. are two secondary forest tree species that currently cover $\leq 3 \%$ of the total forest cover in Europe in pure stands (Spiecker et al., 2009). However, both species are likely to become more abundant and important due to a climate change-driven decrease in fitness and abundance of currently primary forest tree species (Hanewinkel et al., 2012).

Both species have a relative wide distribution in Europe and similar soil requirements. Both species can grow on loamy and clayey soils as long as these are rich in nutrients. Additionally, the study species show phenological and morphological similarities: They flower in April, are insect pollinated, and the wind-dispersed seeds ripen in September-October (Forest Ecology \& Forest Management Group, 2005).

Acer pseudoplatanus is naturally distributed across western, central and southern Europe (Forest Ecology \& Forest Management Group, 2005). This species has moderate site requirements (Krabel and Wolf, 2013) is medium shade tolerant and medium drought tolerant. This species has a wide ecological amplitude and high reproductive capacity (Krabel and Wolf, 2013). Its wide ecological amplitude and high reproductive capacity explain the potential expansion to some European areas such as Sweden and Norway (Weidema and Buchwald, 2010; Krabel and Wolf, 2013).

A. platanoides is a native species in northern and central Europe, in the Kaukasus and Turkey (Forest Ecology \& Forest Management Group, 2005). This species is considered more shade tolerant than A. pseudoplatanus. Some authors indicate that A. platanoides and A. pseudoplatanus are similarly drought tolerant (Forest Ecology \& 


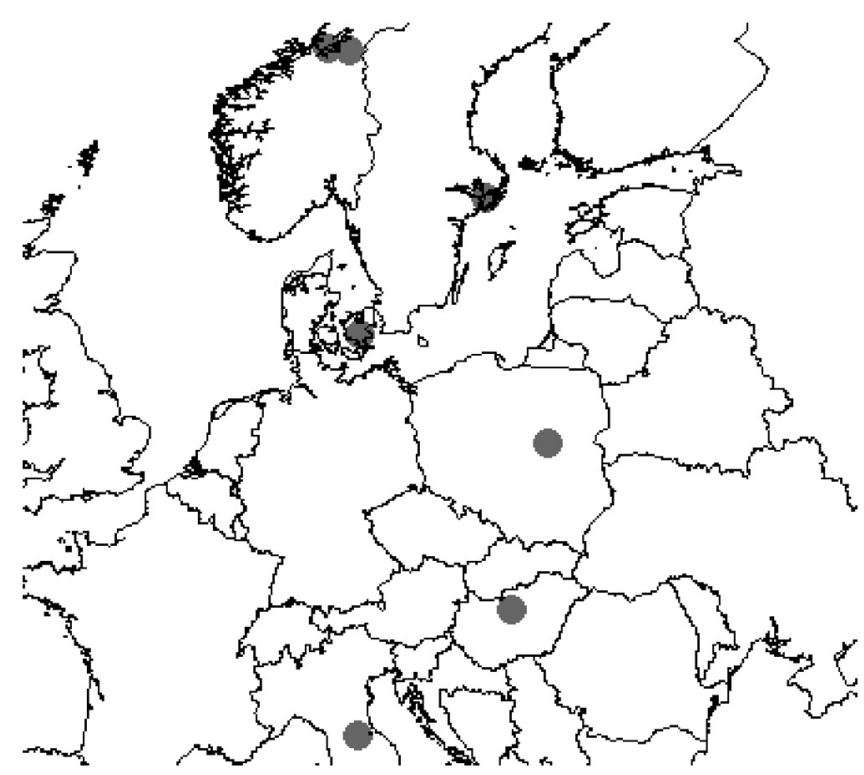

Fig. 1. Location of the countries/regions of seed collection of Acer platanoides and A. pseudoplatanus along a latitudinal gradient.

Forest Management Group, 2005), while others consider A. platanoides more drought tolerant than A. pseudoplatanus (Hemery et al., 2009). Its robust growth and high shade tolerance make this species an important invasive species, especially in North America (Martin, 1999).

With ongoing climate change, both species are expected to move their distribution range northwards and to higher elevations (Hemery et al., 2009). Moreover, it is likely that the susceptibility to pathogens will increase with stress by intense warm and dry conditions (Hemery et al., 2009). Taking into account that the species might be differently susceptible to drought, divergent responses to the projected dryer summer conditions may be expected, including top shoot dieback and premature mortality (Hemery et al., 2009). Moreover, it is known that both Acer species do not show identical growth and water economy. Growth of stem and leaves of $A$. platanoides is faster than in A. pseudoplatanus, and A. platanoides consumes less water per unit of leaf area than A. pseudoplatanus (Braun, 1977). It is thus very likely that these species will be affected differently by climate change. Changes in the soil moisture content might also differently affect the seeds because the seeds of $A$. platanoides are considered orthodox (desiccation-tolerant), while $A$. pseudoplatanus' seeds are recalcitrant (desiccation sensitive) (Hong and Ellis, 1990). Also dormancy break might be affected by climate change, as warming may reduce the number of cold days. $A$. platanoides requires approximately 105 days of cold stratification, while A. pseudoplatanus only needs 49-63 days (Baskin and Baskin, 1998). Finally, A. platanoides shows an inhibition of germination at temperatures above $10-15^{\circ} \mathrm{C}$, but can germinate after a second chilling period (Jensen, 2001), while A. pseudoplatanus shows very good germination at high temperatures such as $25^{\circ} \mathrm{C}$ (Jinks et al., 2006). This dissimilar behaviour underlines the relevance of studying the response to climate change of closely related species, avoiding improper conclusions for the genus level.

\subsection{Experimental design}

Seeds of $A$. platanoides and A. pseudoplatanus were collected in 2012 from four and five regions, respectively. The regions selected for this study were located along a $2200 \mathrm{~km}$ long latitudinal gradient, from Italy through Hungary, Poland, Denmark and Sweden to Norway (Fig. 1). Seeds were either (i) bought from a nurs- ery which could provide exact provenance information (Poland, Denmark and Hungary), or (ii) collected from three forest patches in an area of $40 \mathrm{~km} \times 40 \mathrm{~km}$ (Italy, Central Sweden and Norway). In the latter case, one seed-bearing healthy mother tree was used for seed collection in each forest patch and the seeds were picked from the forest floor immediately after seed dispersal (Italy, Central Sweden and Norway). These locations were selected due the relatively high viability of the seeds produced in these regions in 2011: Italy ( $40.0 \pm 35.3$ S.E. \% viable seeds per tree), Central Sweden $(40.0 \pm 12.0)$ and Norway (55.6 \pm 10.7$)$ (Carón et al., 2014a).

We performed a full factorial experiment with soil heating and watering frequency manipulation, to simulate a total of nine climate change scenarios. We based our experiment on the different representative concentration pathway-scenarios proposed by the Intergovernmental Panel on Climate Change (IPCC, 2013). In Europe, an increase of the air temperature between $0.6^{\circ} \mathrm{C}$ and $4.5^{\circ} \mathrm{C}$ is projected, which in turn will result in an increase of the soil temperature due to the relationship between these factors, but the warming of the air and soil is expected not to be equal due to the natural variation between these factors (see Carón et al., 2015). The mean annual precipitation is also projected to change, and is expected to increase in northern and central Europe and decrease in the Mediterranean area (IPCC, 2013). Moreover, considering the possible changes in precipitation frequency, three watering frequency treatments were applied. The amount of water was expressed as soil moisture content rather than millimetres of rainfall since (i) this is a stronger predictor of the impact on plant establishment than precipitation (Walck et al., 2011), (ii) germination and other early establishment variables are highly dependent on available soil moisture (Kos and Poschlod, 2008), and (iii) it is easier to compare the results with previous studies that used this variable (Vicca et al., 2012; Carón et al., 2014b).

All seeds were cold stratified until dormancy break. The seeds were soaked in water until the desired level of moisture was reached (i.e. $48 \%$ and $38 \%$ for $A$. pseudoplatanus and $A$. platanoides, respectively), after which the seeds were placed under controlled cold conditions $\left(0-1{ }^{\circ} \mathrm{C}\right.$ and $90-95 \%$ humidity) until germination started. Because the stratification time is highly dependent on species and provenance, and to ensure that the seeds from all the provenances were at the same developmental stage at the start of the experiment, seed lots that started to germinate were stored in a freezer at $-2{ }^{\circ} \mathrm{C}$ until the start of the experiment (52 days of difference between the first and the last seed lot germination).

Four seeds of each species and region were randomly sown in each of 12 plastic pots $\left(112 \mathrm{~cm}^{3}, 7 \mathrm{~cm}\right.$ deep $)(4 \times 12=48$ seeds $)$ per treatment, filled with standard potting soil (mean $\mathrm{pH} 6$, nutrient content ratio NPK $15: 10: 11$ at $1 \mathrm{~kg} / \mathrm{m}^{3}$, organic matter $20 \%$ and water holding capacity of $80 \%$ ). The manipulations of the soil temperature were: (1) Control at ambient temperature (the average for the whole period was $19.2 \pm 3.2^{\circ} \mathrm{C}$ (mean $\pm \mathrm{SD}$ ) measured every minute, and averaged and logged every 15 min using Decagon data loggers Em50 ECH2O Logger inside the soil of the pots at $4 \mathrm{~cm}$ depth); (2) warming with $+2.8^{\circ} \mathrm{C}\left(22.0 \pm 2.9^{\circ} \mathrm{C}\right)$, and (3) extreme warming with $+7.0^{\circ} \mathrm{C}\left(26.2 \pm 4.6^{\circ} \mathrm{C}\right)$. Additionally, the watering frequency was manipulated by adding the same total amount of water on each occasion, but in different intervals (one, two or three times per week). The necessary amount of water to be added every week was calculated by weighing three randomly chosen pots per warming treatment and calculating the necessary amount of water to reach field capacity. Then the necessary amount of water was divided by the watering interval assuring that all the treatments received exactly the same amount of water per week but in different intervals. The average weekly amount of water added to each pot during the experiment under each treatment was: $+0{ }^{\circ} \mathrm{C}: 24 \mathrm{ml}$ (control), $+2.8^{\circ} \mathrm{C}: 25 \mathrm{ml}$, and $+7.0^{\circ} \mathrm{C}: 29 \mathrm{ml}$. 
Table 1

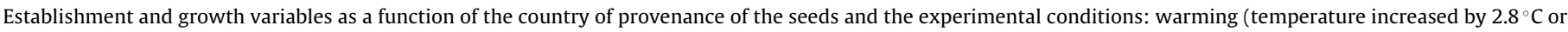
$7.0^{\circ} \mathrm{C}$ compared to the control) and watering frequency (one, two or three times per week).

\begin{tabular}{|c|c|c|c|c|c|}
\hline \multirow[b]{2}{*}{ Establishment variables } & \multicolumn{2}{|l|}{ Acer platanoides } & \multicolumn{3}{|c|}{ Acer pseudoplatanus } \\
\hline & Predictor & LRT & \multicolumn{2}{|c|}{ Predictor } & LRT \\
\hline Germination & $\begin{array}{l}\text { Watering frequency } \\
\text { Seed provenance }\end{array}$ & $\begin{array}{l}\uparrow 6.38^{*} \\
183.69^{* * *}\end{array}$ & \multicolumn{2}{|c|}{$\begin{array}{l}\text { Watering frequency } \\
\text { Seed provenance } \\
\text { Warming }\end{array}$} & $\begin{array}{l}\uparrow 4.49^{*} \\
545.79^{* * *} \\
\downarrow 10.46^{* *}\end{array}$ \\
\hline Survival & Warming & $\downarrow 84.11^{* * * *}$ & \multicolumn{2}{|c|}{$\begin{array}{l}\text { Warming } \times \text { seed provenance } \\
\text { Warming } \times \text { watering frequency } \times \text { seed provenance }\end{array}$} & $\begin{array}{l}13.24^{*} \\
11.68^{*}\end{array}$ \\
\hline Growth & \multicolumn{2}{|l|}{ Predictor } & Scaled dev & Predictor & Scaled dev \\
\hline Total biomass & \multicolumn{2}{|c|}{$\begin{array}{l}\text { Warming } \\
\text { Seed provenance } \\
\text { Warming } \times \text { seed provenance }\end{array}$} & $\begin{array}{l}\downarrow 99.38^{* * *} \\
36.58^{* * *} \\
114.61^{* * *}\end{array}$ & $\begin{array}{l}\text { Warming } \\
\text { Seed provenance } \\
\text { Warming } \times \text { Watering frequency }\end{array}$ & $\begin{array}{l}\downarrow 49.42^{* * *} \\
71.99^{* * *} \\
31.40^{* * *}\end{array}$ \\
\hline Aboveground biomass & \multicolumn{2}{|c|}{$\begin{array}{l}\text { Warming } \\
\text { Seed provenance } \\
\text { Warming } \times \text { seed provenance }\end{array}$} & $\begin{array}{l}\downarrow 88.86^{* * *} \\
28.14^{* * *} \\
103.22^{* * *}\end{array}$ & $\begin{array}{l}\text { Warming } \\
\text { Seed provenance } \\
\text { Warming } \times \text { Watering frequency }\end{array}$ & $\begin{array}{l}\downarrow 43.87^{* * *} \\
42.1^{* * *} \\
25.00^{* * *}\end{array}$ \\
\hline Belowground biomass & \multicolumn{2}{|c|}{$\begin{array}{l}\text { Warming } \\
\text { Seed provenance } \\
\text { Warming } \times \text { seed provenance } \\
\text { Watering frequency } \times \text { seed provenance }\end{array}$} & $\begin{array}{l}\downarrow 92.98^{* * *} \\
40.20^{* * *} \\
106.17^{* * *} \\
32.53^{* * *}\end{array}$ & $\begin{array}{l}\text { Warming } \\
\text { Seed provenance }\end{array}$ & $\begin{array}{l}\downarrow 35.54^{* * *} \\
77.88^{* * *}\end{array}$ \\
\hline Root:shoot ratio & \multicolumn{2}{|l|}{$\begin{array}{l}\text { Warming } \\
\text { Seed provenance }\end{array}$} & $\begin{array}{l}\downarrow 24.33^{* * *} \\
36.10^{* * *}\end{array}$ & $\begin{array}{l}\text { Warming } \\
\text { Seed provenance }\end{array}$ & $\begin{array}{l}\downarrow 10.76^{* *} \\
53.52^{* * *}\end{array}$ \\
\hline Height & \multicolumn{2}{|c|}{$\begin{array}{l}\text { Warming } \\
\text { Seed provenance } \\
\text { Warming } \times \text { seed provenance }\end{array}$} & $\begin{array}{l}\downarrow 64.69^{* * *} \\
32.23^{* * *} \\
89.69^{* * *}\end{array}$ & $\begin{array}{l}\text { Warming } \\
\text { Seed provenance }\end{array}$ & $\begin{array}{l}\downarrow 139.72^{* * *} \\
57.54^{* * *}\end{array}$ \\
\hline
\end{tabular}

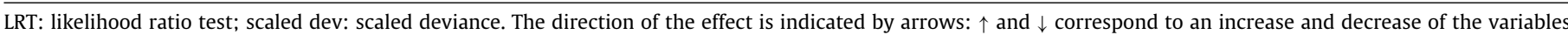
analyzed, respectively.

${ }^{*} P<0.05$.

${ }^{* *} P<0.01$.

${ }^{* * *} P<0.001$.

Warming was achieved through evenly spread soil heating mats (ACD heating mats HMT-A, Oberweidbach Germany). The experiment was installed facing west at the edge of a deciduous forest in Gontrode, Belgium $\left(50^{\circ} 58^{\prime} \mathrm{N}, 3^{\circ} 48^{\prime} \mathrm{E}\right)$, with F. sylvatica, Fraxinus excelsior, Quercus robur and Acer pseudoplatanus dominating the canopy. The location of the experiment was close to the forest edge $(<10 \mathrm{~m})$ but not directly under the forest canopy assuring that the whole experimental area received direct mid-day light without interference of the forest canopy. The pots were placed on top of the soil heating mats, on wooden tables under plastic roofs $(70 \mathrm{~cm}$ above the pots) to exclude the natural precipitation and allow free air exchange. During the experiment, the pots were continuously randomly relocated.

At the end of the experiment (ca. 3 months after sowing), we assessed the regeneration in terms of germination (number of emerged seedlings), survival (number of living seedlings at the end of the experiment) and seedling growth (height, aboveground and belowground biomass and total biomass). Germination was recorded once per week. At the end of the experiment, the seedlings were carefully removed from the soil, the aboveground and belowground parts separated, dried at $60^{\circ} \mathrm{C}$ for $24 \mathrm{~h}$ and weighed.

\subsection{Data analysis}

Generalized linear models (GLM) in R version 3.1.0 ( $R$ Core Team, 2013) were applied. For the binomial data (germination and survival) and continuous data (aboveground, belowground and total biomass, root:shoot ratio and height), we used binomial and Gaussian errors structures, respectively. To fulfil the requirements of normality and homoscedasticity, for both species, the aboveground, belowground and total biomass were log transformed and root:shoot ratio was square root-transformed. Additionally, the height of $A$. platanoides was log-transformed prior to analyses. The temperature treatments $\left(+0^{\circ} \mathrm{C},+2.8^{\circ} \mathrm{C}\right.$ and $\left.+7^{\circ} \mathrm{C}\right)$, the watering frequency treatments (one, two and three times weekly) and the country of seed provenance (Poland, Denmark, Sweden, Norway, Italy and Hungary) were used as fixed effects. The a priori data exploration showed that the seeds' origin (i.e. collected by us vs. purchased from tree nurseries) did not affect the results, therefore, this factor was not included in the analyses. For each variable analysed, first the full model was fitted (all the fixed effects and their interactions), after which models were simplified by dropping first the least significant interaction and then the least significant individual variable at each step. The comparison between models was based on the likelihood ratio test or the scaled deviance for the binomial and Gaussian data, respectively, until all the remaining terms were significant (Zuur et al., 2009).

\section{Results}

\subsection{Establishment variables}

Both species germination and seedlings' performance responded to temperature, watering frequency and the country of origin, with stronger effects of temperature and the country of origin than of watering frequency (Table 1). Seed provenance significantly affected germination in both species; the highest germination of both species was recorded approximately in the centre of the distribution range (Table 1 and Fig. 2). Moreover, germination was 19 and $12 \%$ (A. platanoides) and 16 and $12 \%$ (A. pseudoplatanus) higher when the watering treatment was applied two and three times per week, respectively, compared to the least frequent watering (Table 1, Fig. 2 and Electronic Appendix Tables A1 and A2). Additionally, for A. pseudoplatanus, the temperature increase reduced germination, being $17.3 \%$ lower with $2.8^{\circ} \mathrm{C}$ 


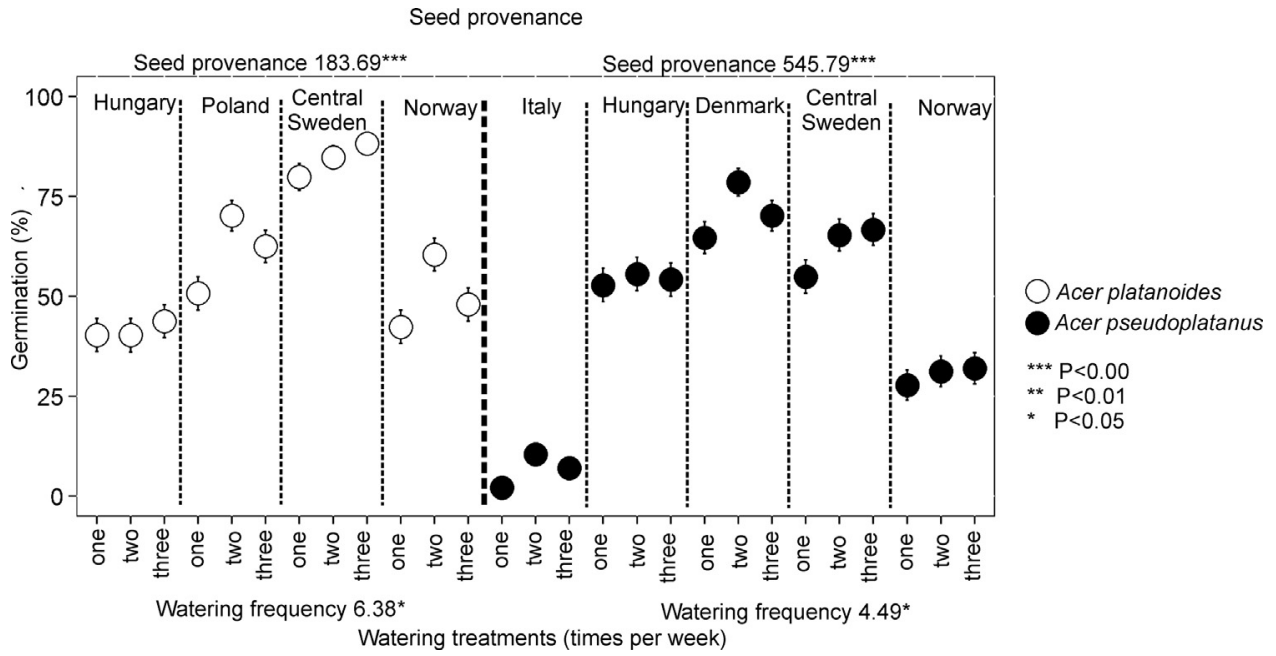

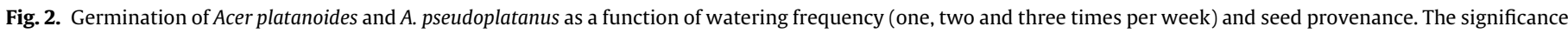
of the factors that are displayed is indicated. The error bars indicate standard errors across 12 replicates of four seeds per provenance and treatment (total $n=3888$ ).

warming than under control conditions (Table 1 and Electronic Appendix Table A2).

Significant differences were observed between the species in terms of seedling survival. A. platanoides' survival decreased with warming, and was, on average across the countries, $49.9 \%$ lower under warmest condition $\left(+7.0^{\circ} \mathrm{C}\right)$ than under control condition (Table 1, Fig. 3 and Electronic Appendix Table A1). Survival of A. pseudoplatanus, on the other hand, responded differently to increases in temperature depending on the country of origin of the seeds (significant warming $\times$ provenance interaction, Table 1 and Fig. 3). Survival of seedlings of seeds from Hungary and Central Sweden increased under the warmest condition $\left(+7.0^{\circ} \mathrm{C}\right)$, while survival of seedlings of seeds from Denmark and Norway declined with warming $\left(+2.8^{\circ} \mathrm{C}\right.$ and $+7.0^{\circ} \mathrm{C}$ ) (Fig. 3). The joint manipulation of temperature and watering frequency differently affected seedling survival depending on the seeds' provenance (Table 1). For example, seedlings from Italian seeds showed a higher survival with warming when watered once per week, but showed reduced survival under warming when watered more often ( 3 times per week). The Central Swedish provenance exhibited a constant increase of survival with warming across all the watering frequencies treatments.

\subsection{Growth variables}

Regarding the biomass variables, both species showed similar responses to the manipulated factors (Table 1 ), despite that the seedlings of $A$. platanoides were much bigger than the seedlings of A. pseudoplatanus (Figs. 4 and 5).

Warming negatively affected the aboveground, belowground and consequently the total biomass of both species. The total biomass was $53.5 \%$ (A. platanoides) and $37.9 \%$ (A. pseudoplatanus) lower in seedlings growing under the warmest condition $\left(+7.0^{\circ} \mathrm{C}\right)$ than under the control temperature treatment $\left(+0^{\circ} \mathrm{C}\right)$ (Fig. 5 and Electronic Appendix Tables A1 and A2). Furthermore, the provenance of the seeds influenced the aboveground, belowground and the total biomass, which generally increased to the north, but the highest values were recorded in Central Sweden (A. platanoides) and Denmark (A. pseudoplatanus). In addition, analyses revealed interactive effects affecting both species (Table 1 ). The aboveground, belowground and total seedling biomass of $A$. platanoides generally decreased with warming, but seedlings grown from seeds of middle latitudes (Poland and Central Sweden) were smaller under a moderate warming $\left(+2.8^{\circ} \mathrm{C}\right)$ than under extreme warming (significant warming $\times$ provenance interaction, Table 1, Fig. 4 and Electronic

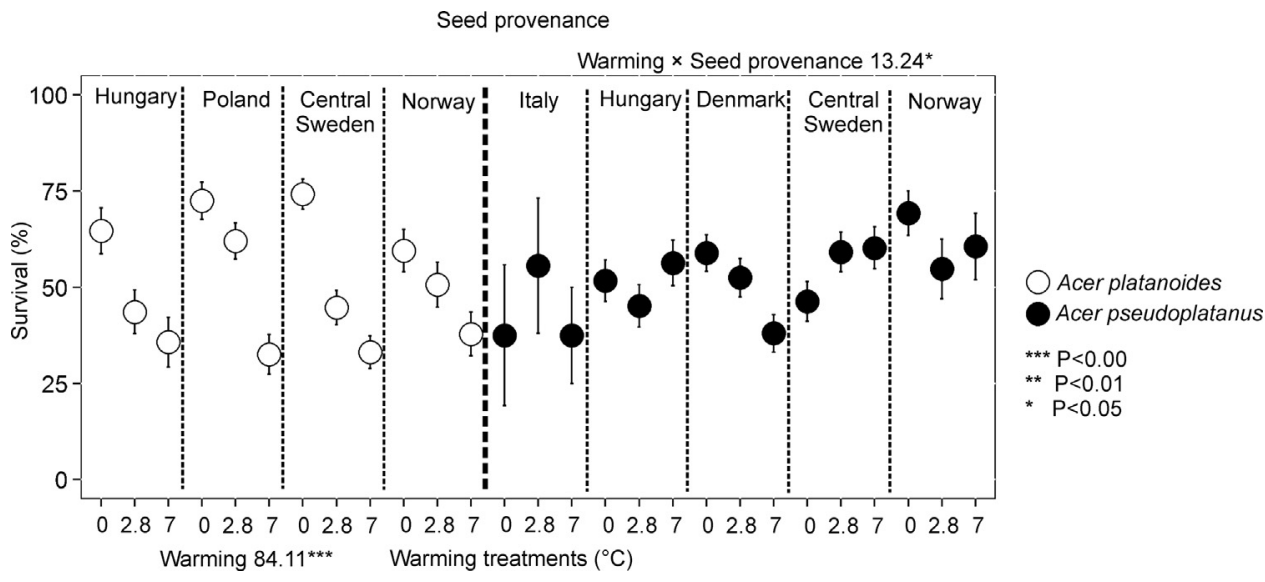

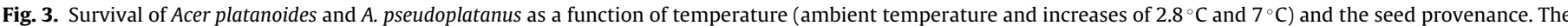

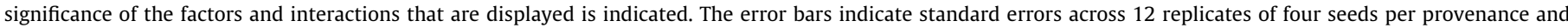
treatment (A. platanoides total $n=1080$, A. pseudoplatanus total $n=992$ ). 

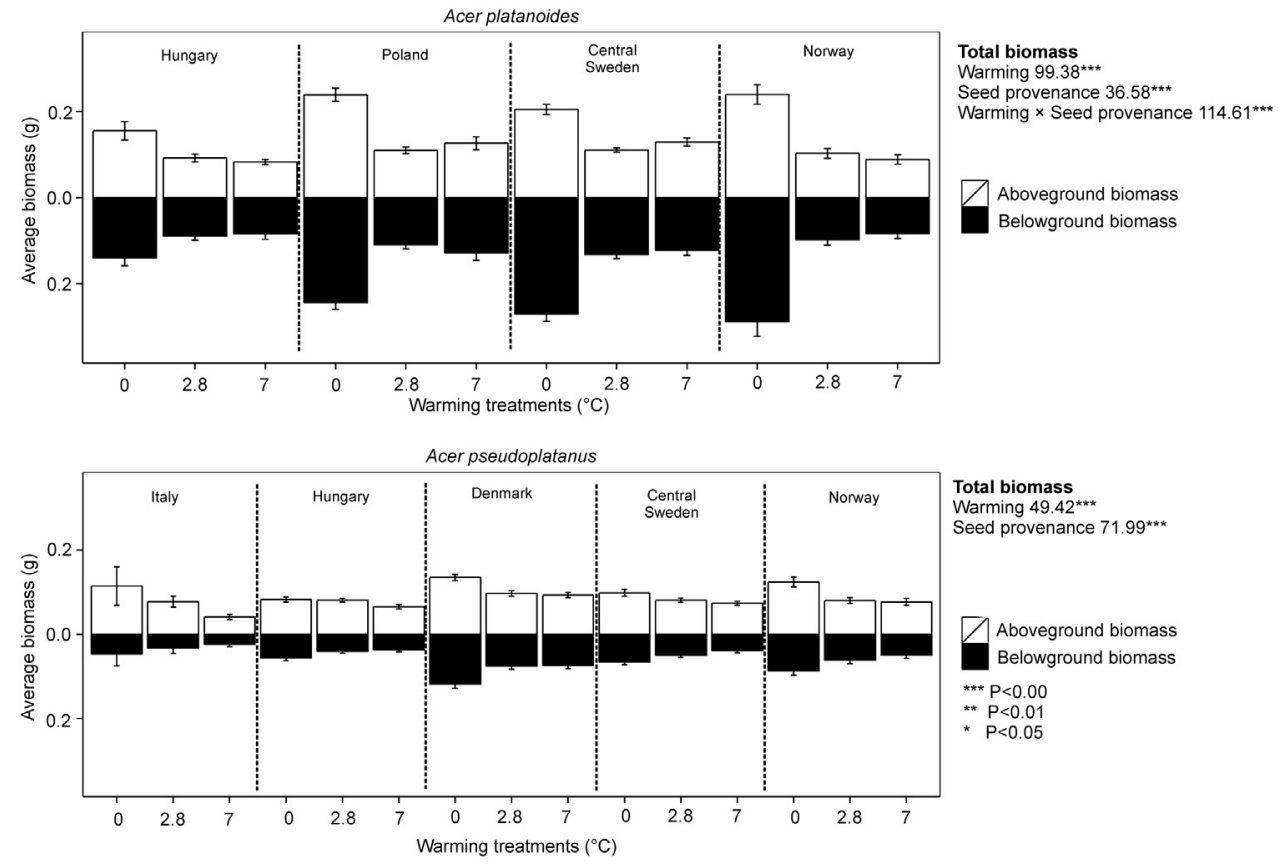

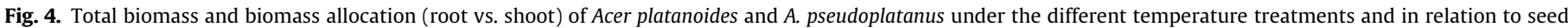

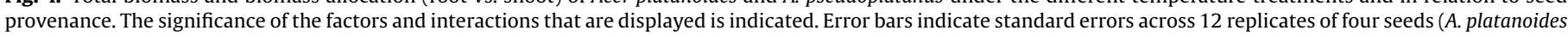
total $n=536$, A. pseudoplatanus total $n=514$ ).

Appendix Table A1). In A. pseudoplatanus, the aboveground biomass and total biomass showed a reduction of 38 and $48 \%$, respectively, when growing under the warmest condition and the most frequent watering treatment $\left(7.0^{\circ} \mathrm{C}\right.$ and watered three times per week) compared with the less frequently watering and unwarmed conditions (control temperature and watered one time per week) (Table 1 and Electronic Appendix Table A2).
The root:shoot ratio of both species depended on the seed provenance and was affected by experimental warming (Table 1). Root:shoot ratios were highest in Central Sweden (A. platanoides) and Denmark (A. pseudoplatanus) (Fig. 4 and Electronic Appendix Tables A1 and A2). Warming decreased the root:shoot ratio in both species (Table 1, Figs. 4 and 5 and Electronic Appendix Tables A1 and A2).

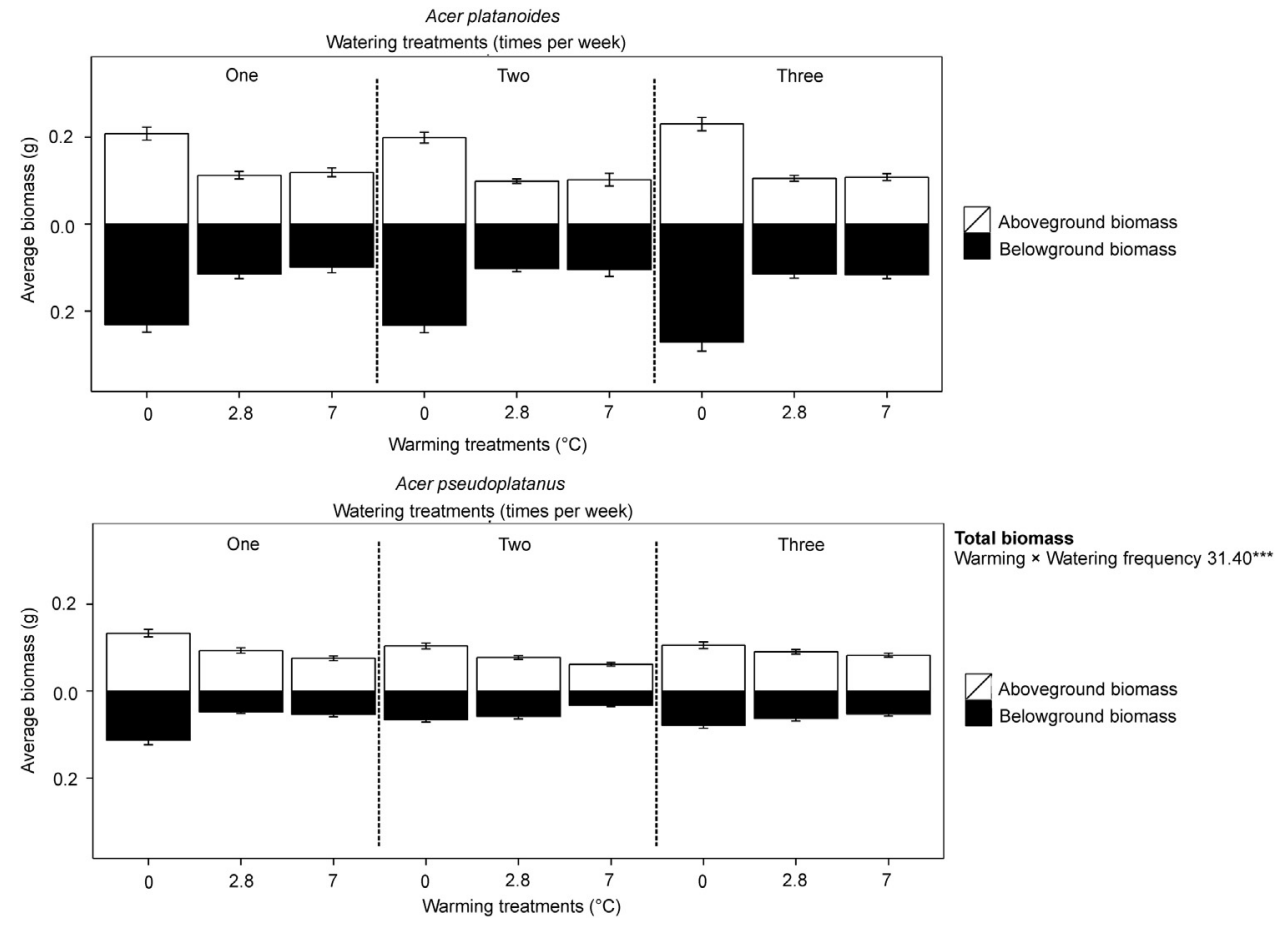

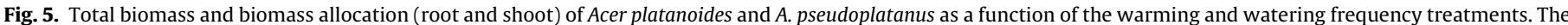

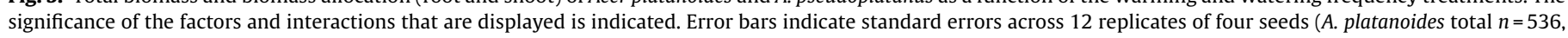
A. pseudoplatanus total $n=514$ ). 
Finally, the height of both species was negatively affected by warming. The seedlings of $A$. platanoides and A. pseudoplatanus were $18.3 \%$ and $24.2 \%$ shorter when growing under the warmest conditions compared to the control (Table 1 and Electronic Appendix Tables A1 and A2). In addition, seedling height appeared to be provenance-specific; seedlings grown from seeds collected in Poland (A. platanoides) or Central Sweden (A. pseudoplatanus) were the tallest. Moreover, the seedlings of $A$. platanoides from the southern and northern provenances (Hungary and Norway) showed a strong height growth reduction under simulated warming $\left(2.8^{\circ} \mathrm{C}\right.$ and $7.0^{\circ} \mathrm{C}$ ), while that was not the case for the central provenances (Table 1 and Electronic Appendix Table A1).

\section{Discussion}

Different responses to warming and watering frequency were observed in both species and among the life phases analysed (i.e. germination, seedling survival and growth). Germination of both species was strongly influenced by the watering frequency and the country of origin of the seeds, while warming was the main factor affecting seedling growth. Overall, temperature and the country of origin of the seeds appeared to be the most important factors affecting germination and seedling survival and growth of these species. The interactive effects between warming, watering frequency and/or seed provenance were less important than initially expected.

The frequency of watering affected seed germination of both species. Precipitation frequency has been shown to affect soil moisture variability (Fay and Schultz, 2009), which in turn may influence germination patterns (Shevtsova et al., 2009; Carón et al., 2014b). Our results, consistent with the observations of Fay \& Schultz (2009), show that cycles of hydration and dehydration (i.e. lower amounts of water, but more frequent watering events) tend to enhance germination. Both species showed different germination percentages according to seed provenance. Germination generally appeared to be higher in seeds from more northerly provenances, probably due to higher northerly seed mass (Carón et al., 2014a), likely caused by a slower seed ripening at lower temperatures, slower seed filling process and therefore a greater total assimilation (Fenner and Thompson, 2005). However, contradicting our hypothesis, seed provenance did not influence seed germination in response to the treatments applied (warming and changes in watering frequency), which indicates that climate change will affect germination of these species similarly in Europe, despite the variable germination rates observed along their distribution range. On the other hand, warming only affected germination of one of the species, A. pseudoplatanus, with germination decreasing at increased temperatures. It is possible that the experimental warming reached a level close to the threshold temperatures for the species' germination (Chmura et al., 2011) and that a similar future warming will affect this species' recruitment by reducing germination probability. The decrease in germination due to warming observed here was not caused by a corresponding negative effect of warming on dormancy break because the stratification process was completed before the beginning of the experiment. Even though dormancy break was not evaluated here, it is likely that both species' dormancy will be differently impacted by climate change. Considering that $A$. platanoides requires more days of cold stratification for successful dormancy break than $A$. pseudoplatanus (Baskin and Baskin, 1998), it is likely that A. platanoides will be impacted more than $A$. pseudoplatanus by the predicted reduction of the amount of chilling days in winter caused by global warming.

Treatment effects on seedling survival differed more between the two species than their effects on germination, apart from the effects of warming on seed germination that were clearly species- specific. Seedling survival of $A$. platanoides decreased under warmer conditions. It is known that warmer conditions tend to enhance physiological processes, thereby also increasing the chances of survival (Chmura et al., 2011). Warmer temperatures at northern latitudes may enhance photosynthesis in boreal and temperate trees due to an increase in the content of photosynthetic pigments, light-saturated photosynthetic rate and quantum yield (Saxe et al., 2001). Effects on photoinhibition and photorespiration are more difficult to generalize because they depend on the species and general climatic conditions of the area but, overall, slightly warmer conditions (ca. $2^{\circ} \mathrm{C}$ ) are expected to promote photoinhibition and photorespiration (Saxe et al., 2001). However, the soil moisture content is also important and might be even more relevant for photosynthesis than temperature per se (Saxe et al., 2001; Chmura et al., 2011). Moreover, it is known that warming not only affects aboveground processes but also can affect soil respiration (root and microbial respiration), nutrient availability and root dynamics which are all important aspects for seedlings' survival (Bai et al., 2010; Zhou et al., 2012). Warming in the range of $0.3-6.0^{\circ} \mathrm{C}$ can indeed increase soil respiration rates by $20 \%$, net $\mathrm{N}$ mineralization rates by $46 \%$, and plant productivity by $19 \%$ (Rustad et al., 2001). The response of soil respiration and mineralization rates to warming not only depends on the temperature change, but also on other factors such as the soil substrate, the organic matter and soil moisture content (Rustad et al., 2001; Saxe et al., 2001). In terms of root dynamics, warming can reduce root biomass while increases in precipitation can increase root biomass (Bai et al., 2010). It is possible that the observed negative effect of warming on $A$. platanoides survival is caused by an excessive warming applied in this experiment. Considering the previous concepts, it is likely that the direction of the impact of climate change on seedling survival will depend on the level of warming experienced by the seedlings but also of many interacting factors as observed for $A$. pseudoplatanus. The survival of $A$. pseudoplatanus was influenced by a complex interaction of warming, seed provenance and watering frequency. Under extreme warming $\left(+7.0^{\circ} \mathrm{C}\right)$, more frequent watering enhanced survival. Extremely warm conditions intensify evapotranspiration, and, consequently, more frequent watering tends to result in higher soil moisture in the upper layers of the soil due to the more intense heat at the bottom of the pots which is in direct contact with the soil heaters. Moreover, as mentioned before, many physiological processes not only depend on the temperature but also the soil moisture content and this can be the cause behind the significance of this interaction. This result not only highlights the relevance of multiple interacting factors (Shaver et al., 2000), but also points to some of the possible problems (i.e. possible notuniform warming of the soil column in the pot) associated with the methods utilized for studying the effects of climate change on plants. However, because the pots used in this experiment were relatively small $\left(112 \mathrm{~cm}^{3}\right)$, it is likely that no significant differences in warming existed along the soil column or that the high specific heat of water played a role in the significance of this interaction regarding seedling survival. Finally, it is important to consider that under future climatic conditions, warming of the air will be accompanied by potentially non-uniform warming of the soil. To clarify the relevance and role of all these aspects and to unravel the effect of temperature and watering frequency, more experiments using different methods can be performed employing, for example, growth chambers (e.g. Deines et al., 2007; De Frenne et al., 2012). In addition, A. pseudoplatanus also showed provenance-specific responses to increases in temperature. The survival of seedlings grown from seeds collected in Hungary and Central Sweden was in general higher under warmer conditions, while survival of seedlings grown from seeds collected in Denmark and Norway showed an opposite response (i.e. lower survival under warmer conditions). This is likely related to the environmental conditions experienced by 
the mother tree during seed production (Johnsen et al., 2005a,b; Skrøppa et al., 2010; Carón et al., 2014a). While we lack detailed information on environmental conditions experienced by all the mother trees, previous studies suggest that the observed pattern (different survival according to the seed provenance under changing environmental conditions) is likely related to the temperature experienced during seed production (Johnsen et al., 2005a,b; Carón et al., 2014a,b). Nevertheless, our results clearly point out the influence of seed provenance on seedling responses to climate change (Atzmon et al., 2004; Thiel et al., 2014). Additionally, the possibility of the presence of local adaptations should be analysed (Kawecki and Ebert, 2004) through the use of, for instance, transplant experiments (De Frenne et al., 2011; HilleRisLambers et al., 2013; Ibáñez and McCarthy-Neumann, 2014).

Regarding seedling growth, the total biomass was much more affected by warming than by the changes in watering frequency. The absence of effects of watering frequency (individual factor) is surprising given that previous experiments demonstrated effects of precipitation amount (e.g. Dreesen et al., 2012; Carón et al., 2014a) and of soil moisture variability (e.g. Fay et al., 2002, 2012) on growth. However, it is possible that the high organic matter content (20\%) of the potting soil used in this experiment induced a high water retention capacity, therefore, irrespective of the treatments applied, the seedlings never experienced strong drought stress related to the differences in watering frequency. Conversely, warming negatively affected seedling growth in both species despite that under warmer conditions, the physiological processes of plants including photosynthesis and respiration increase as long as the water content is adequate (Chmura et al., 2011). However, the increase of photosynthesis and respiration might not be equal and can, in some cases, negatively affect species growth if the fraction of gross photosynthetic production consumed by respiration becomes too high (Saxe et al., 2001). Growth of $A$. platanoides was strongly reduced in both warming treatments $\left(+2.8^{\circ} \mathrm{C}\right.$ and $\left.+7.0^{\circ} \mathrm{C}\right)$, while growth of $A$. pseudoplatanus also declined under warmer conditions but not as abruptly as in A. platanoides. In a previous study, similar results were obtained, with both species not showing a positive growth response to warming (Carón et al., 2014b). Warming reduced belowground and aboveground biomass. However, the stronger negative effect of warming on belowground biomass resulted in a reduction of the root:shoot ratio under warmer conditions. It was observed before that warming can decrease annual root production (Bai et al., 2010) and fine root biomass (Wan et al., 2004) but also can decrease root mortality (Bai et al., 2010). However, other studies suggest that the evapotranspiration caused by warming decreases the soil moisture content and can increase the proportional allocation towards roots in order to facilitate plant water uptake. This effect, however, might also suppress overall root growth (Rustad et al., 2001; Zhou et al., 2012). Moreover, the reduction of the root:shoot ratio might also be linked to an imbalance between photosynthesis and respiration. The relevance of interacting factors was especially clear for A. pseudoplatanus' growth. The interaction between factors has been highlighted as key when predicting species responses to climate change (Bai et al., 2010). The results reported here corroborate the relevance of studying interacting factors of climate change. Regarding the influence of the provenance on seedling's performance, it is interesting to note that $A$. pseudoplatanus did not show provenance-specific growth responses to the treatments applied. This indicates that, independent of the provenance of $A$. pseudoplatanus seeds, the seedlings are equally affected in terms of growth. However, A. platanoides showed provenance-specific responses in biomass growth as observed earlier for other tree species such as F. sylvatica where the marginal provenances showed a more stable performance under drought but apparently there was a trade-off between drought tolerance and growth (Thiel et al., 2014).
Considering the results of this study, it is possible to suggest that both species will be affected by changes in some climatic factors (warming and precipitation frequency). Divergent effects of changes in climatic factors can be expected on different phases of plant recruitment, and their impacts may differ in direction and magnitude. Stronger effects of warming were observed for both species, while watering frequency appeared to be less important. Further research should focus on more realistic simulations of changes in precipitation frequency with possibly longer intermediate dry periods (see, for instance, Dreesen et al., 2012) to more clearly show the relevance of this factor on these species' recruitment. Moreover, due to the frequent divergent responses of seeds and seedlings along the gradient analysed, it is likely that the impact will not be homogenous across Europe. In general, more central European provenances performed better irrespective whether seeds were collected from trees growing in natural forests or were purchased from nurseries. These results point out the relevance of performing more experiments where different provenances are tested under simulated future climatic conditions, including transplant experiments to analyse the presence of local adaptation and to deliver urgently-needed information for the development of strategies of forest adaptation in the context of climate change (Pereira et al., 2010; Bellard et al., 2012).

\section{Acknowledgments}

We thank the Research Foundation-Flanders (FWO) for funding the Scientific Research Network 'FLEUR' (www.fleur.ugent.be) allowing the seed collection. The experiment was performed and this paper was written while MMC held a PhD fellowship from the Erasmus Mundus funding through the EuroTango project and PDF held a postdoctoral fellowship from the FWO.

\section{Appendix A. Supplementary data}

Supplementary data associated with this article can be found, in the online version, at http://dx.doi.org/10.1016/j.flora.2015.05.005

\section{References}

Anderegg, W.R.L., Kane, J.M., Anderegg, L.D.L., 2013. Consequences of widespread tree mortality triggered by drought and temperature stress. Nat. Clim. Change 3, 30-36.

Atzmon, N., Moshe, Y., Schiller, G., 2004. Ecophysiological response to severe drought in Pinus halepensis Mill. trees of two provenances. Plant Ecol. 171, $15-22$.

Bai, W., Wan, S., Niu, S., Liu, W., Chen, Q., Wang, Q., Zhang, W., Han, X., Li, L., 2010. Increased temperature and precipitation interact to affect root production, mortality, and turnover in a temperate steppe: implications for ecosystem C cycling. Global Change Biol. 16, 1306-1316.

Baskin, C.C., Baskin, J.M., 1998. Seeds. In: Ecology, Biogeography, and Evolution of Dormancy and Germination. Academic Press, San Diego, California, USA.

Bellard, C., Bertelsmeier, C., Leadley, P., Thuiller, W., Courchamp, F., 2012. Impacts of climate change on the future of biodiversity. Ecol. Lett. 15, 365-377.

Braun, H.J., 1977. Zum wachstum und zur produktivität des wasserverbrauches der baumarten Acer platanoides L., Acer pseudoplatanus L. und Fraxinus excelsior L. Zeitschrift Pflanzenphysiol. 84, 459-462.

Carón, M.M., De Frenne, P., Brunet, J., Chabrerie, O., Cousins, S.A.O., De Backer, L., Diekmann, M., Graae, B.J., Heinken, T., Kolb, A., Naaf, T., Plue, J., Selvi, F., Strimbeck, G.R., Wulf, M., Verheyen, K., 2014a. Latitudinal variation in seeds characteristics of Acer platanoides and A. pseudoplatanus. Plant Ecol. 215, 911-925.

Carón, M.M., De Frenne, P., Brunet, J., Chabrerie, O., Cousins, S.A.O., De Backer, L., Decocq, G., Diekmann, M., Heinken, T., Kolb, A., Naaf, T., Plue, J., Selvi, F. Strimbeck, G.R., Wulf, M., Verheyen, K., 2014b. Interacting effects of warming and drought on regeneration and early growth of Acer pseudoplatanus and A. platanoides. Plant Biol. 17, 52-62.

Carón, M.M., De Frenne, P., Brunet, J., Chabrerie, O., Cousins, S.A.O., Decocq, G. Diekmann, M., Graae, B.J., Heinken, T., Kolb, A., Lenoir, J., Naaf, T., Plue, J., Selvi, F., Wulf, M., Verheyen, K., 2015. Divergent regeneration responses of two closely related tree species to direct abiotic and indirect biotic effects of climate change. For. Ecol. Manage. 342, 21-29.

Chaoyang, W., Chen, J.M., Pumpanen, J., Cescatti, A., Marcolla, B., Blanken, P.D., Ardö, J., Yanhong, T., Magliulo, V., Georgiadis, T., Soegaard, H., Cook, D.R., 
Harding, R.J., 2012. An underestimated role of precipitation frequency in regulating summer soil moisture. Environ. Res. Lett. 7, 24011

Chmura, D.J., Anderson, P.D., Howe, G.T., Harrington, C.A., Halofsky, J.E., Peterson, D.L., Shaw, D.C., Brad StClair, J., 2011. Forest responses to climate change in the northwestern United States: Ecophysiological foundations for adaptive management. For. Ecol. Manage. 261, 1121-1142.

Christensen, J.H., Krishna Kumar, K., Aldrian, E., An, S.-I., Cavalcanti, I.F.A., de Castro, M., Dong, W., Goswami, P., Hall, A., Kanyanga, J.K., Kitoh, A., Kossin, J., Lau, N.-C., Renwick, J., Stephenson, D.B., Xie, S.-P., Zhou, T., 2013. Climate Phenomena and their Relevance for Future Regional Climate Change. In: Stocker, T.F., Qin, D., Plattner, G.-K., Tignor, M., Allen, S.K., Boschung, J., Nauels, A., Xia, Y., Bex, V., Midgley, P.M. (Eds.), In: Climate Change 2013: The Physical Science Basis. Contribution of Working Group I to the Fifth Assessment Report of the Intergovernmental Panel on Climate Change. Cambridge University Press, Cambridge, United Kingdom and New York, NY, USA, pp. 1217-1308, http://dx.doi.org/10.1017/CBO9781107415324.028

De Frenne, P., Brunet, J., Shevtsova, A., Kolb, A., Graae, B.J., Chabrerie, O., Cousins, S.A., Decocq, G., De Schrijver, A.N., Diekmann, M., Gruwez, R., Heinken, T., Hermy, M., Nilsson, C., Stanton, S., Tack, W., Willaert, J., Verheyen, K., 2011. Temperature effects on forest herbs assessed by warming and transplant experiments along a latitudinal gradient. Global Change Biol. 17, 3240-3253.

De Frenne, P., Graae, B.J., Brunet, J., Shevtsova, A., De Schrijver, A., Chabrerie, O., Cousins, S.A.O., Decocq, G., Diekmann, M., Hermy, M., Heinken, T., Kolb, A., Nilsson, C., Stanton, S., Verheyen, K., 2012. The response of forest plant regeneration to temperature variation along a latitudinal gradient. Ann. Bot. 109, 1037-1046.

De Frenne, P., Graae, B.J., Rodríguez-Sánchez, F., Kolb, A., Chabrerie, O., Decocq, G., De Kort, H., De Schrijver, A., Diekmann, M., Eriksson, O., Gruwez, R., Hermy, M., Lenoir, J., Plue, J., Coomes, D.A., Verheyen, K., 2013. Latitudinal gradients as natural laboratories to infer species' responses to temperature. J. Ecol. 101, 493-501.

Deines, L., Rosentreter, R., Eldridge, D.J., Serpe, M.D., 2007. Germination and seedling establishment of two annual grasses on lichen-dominated biological soil crusts. Plant Soil 295, 23-35.

Den Ouden, J., Muys, B., Mohren, F., Verheyen, K., 2010. Bosecolgie en Bosbeheer. Uitgeverij Acco, Leuven, Belgium.

Dreesen, F.E., De Boeck, H.J., Janssens, I.A., Nijs, I., 2012. Summer heat and drought extremes trigger unexpected changes in productivity of a temperate annual/biannual plant community. Environ. Exp. Bot. 79, 21-30.

Dunnett, N.P., Grime, J.P., 1999. Competition as an amplifier of short-term vegetation responses to climate: an experimental test. Funct. Ecol. 13 388-395.

Fay, P.A., Schultz, M.J., 2009. Germination, survival, and growth of grass and forb seedlings: effects of soil moisture variability. Acta Oecol. 35, 679-684.

Fay, P.A., Carlisle, J.D., Danner, B.T., Lett, M.S., McCarron, J.K., Stewart, C., Knapp, A.K., Blair, J.M., Collins, S.L., 2002. Altered rainfall patterns, gas exchange, and growth in grasses and forbs. Int. J. Plant Sci. 163, 549-557.

Fay, P.A., Carlisle, J.D., Knapp, A.K., Blair, J.M., Collins, S.L., 2003. Productivity responses to altered rainfall patterns in a C4-dominated grassland. Oecologia $137,245-251$

Fay, P.A., Jin, V.L., Way, D.A., Potter, K.N., Gill, R.A., Jackson, R.B., Wayne Polley, H., 2012. Soil-mediated effects of subambient to increased carbon dioxide on grassland productivity. Nat. Clim. Change 2, 742-746.

Fenner, M., Thompson, K., 2005. The Ecology of Seeds. Cambridge University Press, New York.

Forest Ecology and Forest Management Group, 2005. Tree Database. Wageningen University http://www.wageningenur.nl/en/Expertise-Services/Chair-groups/ Environmental-Sciences/Forest-Ecology-and-Forest-Management-Group/ Education/Tree-database.htm

Fukami, T., Wardle, D.A., 2005. Long-term ecological dynamics: reciprocal insights from natural and anthropogenic gradients. Proc. R. Soc. B Biol. Sci. 272, 2105-2115.

Hanewinkel, M., Cullmann, D.A., Schelhaas, M.-J., Nabuurs, G.-J., Zimmermann, N.E., 2012. Climate change may cause severe loss in the economic value of European forest land. Nat. Clim. Change 3, 203-207.

Hedhly, A., Hormaza, J.I., Herrero, M., 2008. Global warming and sexual plant reproduction. Trends Plant Sci. 14, 30-36.

Hemery, G.E., Clark, J.R., Aldinger, E., Claessens, H., Malvolti, M.E., O'Connor, E., Raftoyannis, Y., Savill, P.S., Brus, R., 2009. Growing scattered broadleaved tree species in Europe in a changing climate: a review of risks and opportunities. Forestry 83, 65-81.

HilleRisLambers, J., Harsch, M.A., Ettinger, A.K., Ford, K.R., Theobald, E.J., 2013. How will biotic interactions influence climate change-induced range shifts? Ann N. Y. Acad. Sci. 1297, 112-125.

Hong, T.D., Ellis, R.H., 1990. A comparison of maturation drying germination, and desiccation tolerance between developing seeds of Acer pseudoplatanus L. and Acer platanoides L. New Phytol. 116, 589-596.

Ibáñez, I., McCarthy-Neumann, S., 2014. Integrated assessment of the direct and indirect effects of resource gradients on tree species recruitment. Ecology 95, 364-375.

IPCC, 2012. Managing the risks of extreme events and disasters to advance climate change adaptation. In: A Special Report of Working Groups I and II of the Intergovernmental Panel on Climate Change. Cambridge University Press, New York, USA.

IPCC, 2013. Climate change 2013: The physical science basis. contribution of working group i to the fifth assessment report of the intergovernmental panel on climate change. Cambridge University Press, Cambridge, United Kingdom and New York, NY, USA.

Jensen, M., 2001. Temperature relations of germination in Acer platanoides L. seeds Scand. J. For. Res. 16, 404-414.

Jinks, R.L., Willoughby, I., Baker, C., 2006. Direct seeding of ash (Fraxinus excelsior L.) and sycamore (Acer pseudoplatanus L.): the effects of sowing date, pre-emergent herbicides, cultivation, and protection on seedling emergence and survival. For. Ecol. Manage. 237, 373-386.

Johnsen, Ø., Dæhlen, O.G., Østreng, G., Skrøppa, T., 2005a. Daylength and temperature during seed production interactively affect adaptive performance of Picea abies progenies. New Phytol. 168, 589-596.

Johnsen, Ø., Fossdal, C.G., Nagy, N., Mølman, J., Dæhlen, O.G., Skrøppa, T., 2005b. Climatic adaptation in Picea abies progenies is affected by the temperature during zygotic embryogenesis and seed maturation. Plant Cell Environ. 28, 1090-1102.

Kawecki, T.J., Ebert, D., 2004. Conceptual issues in local adaptation. Ecol. Lett. 7, 1225-1241.

Kos, M., Poschlod, P., 2008. Correlates of inter-specific variation in germination response to water stress in a semi-arid savannah. Basic Appl. Ecol. 9, 645-652.

Krabel, D., Wolf, H., 2013. Sycamore Maple (Acer psuedoplatanus L.). In: Pâques, L.E. (Ed.), Forest Tree Breeding in Europe. Current State-of-the-Art and Perspectives. Springer, Dordrecht Heidelberg, New York, London, pp. 373-402.

Lewis, J.D., Olszyk, D., Tingey, D.T., 1999. Seasonal patterns of photosynthetic light response in Douglas-fir seedlings subjected to elevated atmospheric $\mathrm{CO}_{2}$ and temperature. Tree Physiol. 19, 243-252.

Martin, P.H., 1999. Norway maple (Acer platanoides) invasion of a natural forest stand: understory consequence and regeneration pattern. Biol. Invasions 1 , 215-222.

McCarragher, S.R., Goldblum, D., Rigg, L.S., 2011. Geographic variation of germination growth, and mortality in Sugar maple (Acer saccharum) common garden and reciprocal dispersal experiments. Phys. Geogr. 32, 1-21.

Milbau, A., Graae, B.J., Shevtsova, A., Nijs, I., 2009. Effects of a warmer climate on seed germination in the subarctic. Ann. Bot. 104, 287-296.

North, M., Oakley, B., Fiegener, R., Gray, A., Barbour, M., 2005. Influence of light and soil moisture on Sierran mixed-conifer understory communities. Plant Ecol. $177,13-24$.

Peñuelas, J., Sardans, J., Estiarte, M., Ogaya, R., Carnicer, J., Coll, M., Barbeta, A., Rivas-Ubach, A., Llusià, J., Garbulsky, M., Filella, I., Jump, A.S., 2013. Evidence of current impact of climate change on life: a walk from genes to the biosphere. Global Change Biol. 19, 2303-2338

Pereira, H.M., Leadley, P.W., Proença, V., Alkemade, R., Scharlemann, J.P.W., Fernandez-Manjarrés, J.F., Araújo, M.B., Balvanera, P., Biggs, R., Cheung, W.W.L., Chini, L., Cooper, H.D., Gilman, E.L., Guénette, S., Hurtt, G.C., Huntington, H.P., Mace, G.M., Oberdorff, T., Revenga, C., Rodrigues, P., Scholes, R.J., Sumaila, U.R., Walpole, M., 2010. Scenarios for global biodiversity in the 21 st century. Science 330, 1496-1501.

Piper, F.I., Fajardo, A., Cavieres, L.A., 2013. Simulated warming does not impair seedling survival and growth of Nothofagus pumilio in the southern Andes. Perspect. Plant Ecol. Evol. Syst. 15, 97-105.

R Core Team, 2013. R: A Language and Environment for Statistical Computing. R Foundation for Statistical Computing, Vienna, Austria http://www.R-project. org/

Rapp, J.M., Silman, M.R., Clark, J.S., Girardin, C.A.J., Galiano, D., Tito, R., 2012. Intraand interspecific tree growth across a long altitudinal gradient in the Peruvian Andes. Ecology 93, 2061-2072.

Rustad, L.E., Campbell, J.L., Marion, G.M., Norby, R.J., Mitchell, M.J., Hartley, A.E., Cornelissen, J.H.C., Gurevitch, J., GCTE-NEWS, 2001. A meta-analysis of the response of soil respiration, net nitrogen mineralization, and aboveground plant growth to experimental ecosystem warming. Oecologia 126, 543-562.

Saxe, H., Cannell, M.G.R., Johnsen, Ø., Ryan, M.G., Vourlitis, G., 2001. Tree and forest functioning in response to global warming. New Phytol. 149, 369-400.

Schneider, A.C., Lee, T.D., Kreiser, M.A., Nelson, G.T., 2014. Comparative and interactive effects of reduced precipitation frequency and volume on the growth and function of two perennial grassland species. Int. J. Plant Sci. 175 $702-712$.

Seghieri, J., Vescovo, A., Padel, K., Soubie, R., Arjounin, M., Boulain, N., Rosnay, P., de Galle, S., Gosset, M., Mouctar, A.H., Peugeot, C., Timouke, F., 2009. Relationships between climate, soil moisture and phenology of the woody cover in two sites located along the West African latitudinal gradient. J. Hydrol. 375, 78-89.

Shaver, G.R., Canadell, J., Chapin, F.S., Gurevitch, J., Harte, J., Henry, G., Ineson, P., Jonasson, S., Melillo, J., Pitelka, L., Rustad, L., 2000. Global warming and terrestrial ecosystems: a conceptual framework for analysis. Bioscience 50, $871-882$.

Shevtsova, A., Graae, B.J., Jochum, T., Milbau, A., Kockelbergh, F., Beyens, L., Nijs, I., Shevtosova, A., 2009. Critical periods for impact of climate warming on early seedling establishment in subarctic tundra. Global Change Biol. 15, 2662-2680.

Skrøppa, T., Tollefsrud, M.M., Sperisen, C., Johnsen, Ø., 2010. Rapid change in adaptive performance from one generation to the next in Picea abies-Central European trees in a Nordic environment. Tree Genet. Genomes 6, 93-99.

Spiecker, H., Hein, S., Makonnen-Spiecker, K., Thies, M. (Eds.), 2009. In Valuable Broadleaved Forests in Europe. EFI Research-Report 22. European Forest Institute, Joensuu, Finland, p. 256

Thiel, D., Kreyling, J., Backhaus, S., Beierkuhnlein, C., Buhk, C., Egen, K., Huber, G., Konnert, M., Nagy, L., Jentsch, A., 2014. Different reactions of central and marginal provenances of Fagus sylvatica to experimental drought. Eur. J. For. Res. 133, 247-260. 
Van Mantgem, P.J., Stephenson, N.L., Byrne, J.C., Daniels, L.D., Franklin, J.F., Fulé, P.Z., Harmon, M.E., Larson, A.J., Smith, J.M., Taylor, A.H., Veblen, T.T., 2009. Widespread increase of tree mortality rates in the western United States. Science 323, 521-524.

Vicca, S., Gilgen, A.K., Camino Serrano, M., Dreesen, F.E., Dukes, J.S., Estiarte, M., Gray, S.B., Guidolotti, G., Hoeppner, S.S., Leakey, A.D.B., Ogaya, R., Ort, D.R., Ostrogovic, M.Z., Rambal, S., Sardans, J., Schmitt, M., Siebers, M., Van der Linden, L., Van Straaten, O., Granier, A., 2012. Urgent need for a common metric to make precipitation manipulation experiments comparable. New Phytol. $195,518-522$.

Walck, J.L., Hidayati, S., Dixon, K.W., Thompson, K., Poschlod, P., 2011. Climate change and plant regeneration from seed. Global Change Biol. 17, 2145-2161.

Wan, S., Norby, R.J., Pregitzer, K.S., Ledford, J., O'Neill, E.G., 2004. $\mathrm{CO}_{2}$ enrichment and warming of the atmosphere enhance both productivity and mortality of maple tree fine roots. New Phytol. 162, 437-446.
Wang, G. 2005. Agricultural drought in a future climate: results from 15 global climate models participating in the IPCC 4th assessment. Clim. Dyn. 25 739-753.

Weidema, I., Buchwald, E., 2010. NOBANIS - Invasive Alien Species Fact Sheet Acer pseudoplatanus [WWW Document]. Online Database Eur. Netw. Invasive Alien Species - NOBANIS. URL www.nobanis.org

Zhou, X., Fei, S., Sherry, R., Luo, Y., 2012. Root biomass dynamics under experimental warming and doubled precipitation in a tallgrass prairie. Ecosystems 15, 542-554.

Zuur, A.F., Ieno, E.N., Walker, N.J., Saveliev, A.A., Smith, G.M., 2009. Mixed Effects Models and Extensions in Ecology with R. Springer, New York, USA. 